\title{
Underground struggles: The early life of Jack Hodgson ${ }^{1}$ Duncan Money
}

Text version of my chapter that was published in Klaas van Walraven (ed.), The Individual in African History: The Importance of Biography in African Historical Studies (Brill: Leiden \& Boston, 2020), pp. 170-193. https://doi.org/10.1163/9789004407824_008

\section{Introduction}

Following the death of Percy 'Jack' Hodgson, in exile in London in 1977, Oliver Tambo, then president of the African National Congress (ANC), delivered a moving tribute to his widow Rica: 'What Jack gave in service to our people, to our Movement and struggle, to all South Africa, neither death nor time can take away'. ${ }^{2}$ Other vivid tributes were broadcast more widely, such was Hodgson's stature in the anti-apartheid movement as a former defendant in the Treason Trial, when 56 leaders of this nascent movement were arrested for high treason in 1956, and central figure in Umkhonto we Sizwe (MK). From Luanda, MK commander Ronnie Kasrils declared on the ANC's Radio Freedom that Hodgson was 'the son of a worker; he learnt his politics, not in the classroom, but on the mines of the Reef, the diamond field and the copper belt'. ${ }^{3}$ This was true, but the politics Hodgson learnt and espoused in mining regions across Southern Africa were certainly not those of the African nationalist movement he later joined. In fact, they could be regarded as the opposite.

\footnotetext{
${ }^{1} \mathrm{I}$ am grateful for the assistance and insights generously provided by Spencer Hodgson, Ronnie Kasrils and Franziska Rueedi. More generally, I would like to thank seminar audiences at the University of Witwatersrand and the University of Pretoria as well as attendees at 'The Individual in African History' workshop at Leiden University for their helpful feedback. Most importantly, this chapter owes a considerable debt to Sylvia Neame, who carried out eight in-depth interviews with Jack Hodgson in 1968 and shared with me corrected versions of her notes from those interviews. The interviews were not recorded and consist of Neame's handwritten notes taken during the interviews.

2 Tambo's letter was reprinted in 'Jack's fight against fascism', Sechaba, 12 (second quarter, 1978).

${ }^{3}$ Historical Papers Archive, University of the Witwatersrand (HPA), A2729 E3, Script for ANC Radio Freedom, 12 December 1977.
} 
[picture Jack Hodgson as young man]

This chapter focuses on the life of Jack Hodgson from the 1910s to the 1940s, before he became a man whose politics and actions Tambo expressed such profound appreciation for. Biography forms a central part of South African historiography. Most leading figures in the African nationalist movement have been the subject of biographies, along with many other leading political figures. ${ }^{4}$ There is no biography of Hodgson and, as will be seen, there has been little information available on his earlier life prior to this present chapter. ${ }^{5}$ Yet, this chapter does not solely examine Hodgson's life to fill a perceived gap. There are two reasons why his biography illuminates wider themes in Southern African history. First, his life sheds light on white societies in Southern Africa in the first half of the twentieth century. Tens of thousands of whites experienced the same injustices which Hodgson did in these years and participated in the political and labour movements he did, yet few of them came to the same conclusions as he did. His life is a vivid illustration that the impact of material conditions and experiences were not homogenous, and of the role of subjectivity. As will be seen, he remained hostile both to the state and white employers, though most other whites like him made their peace with both.

\footnotetext{
${ }^{4}$ For biographies of African nationalists, see R. Barnard, The Cambridge Companion to Nelson Mandela (Cambridge, 2014); L. Callinicos, Oliver Tambo. Beyond the Engeli Mountains (Johannesburg, 2004); S. Clingman, Bram Fischer: Afrikaner Revolutionary (Cape Town, 1998); S.D. Gish, Alfred B. Xuma: African, American, South African (New York, 2000); B. Pogrund, How Can Man Die Better: The Life of Robert Sobukwe (Johannesburg, 2006); B. Willan, Sol Plaatje: South African Nationalist 1876-1932 (London, 1984). For recent biographies of other major political figures in South Africa see L. Koorts, D.F. Malan and the Rise of Afrikaner Nationalism (Cape Town, 2014); A. Desai and G. Vahed, The South African Gandhi: Stretcher-Bearer of Empire (Stanford, 2015); A. Drew, Between Empire and Revolution: A Life of Sidney Bunting, 1873-1936 (London, 2007). Several MK veterans also produced autobiographies, many of which mention Jack Hodgson. The most famous, of course, is N. Mandela, The Long Walk to Freedom: The Autobiography of Nelson Mandela (London, 1994), but see also R. Bernstein, Memory Against Forgetting: Memoirs from a Life in South African Politics 1938-1964 (Johannesburg, 1999), D. Goldberg, The Mission: A Life for Freedom in South Africa (Johannesburg, 2010); R. Kasrils, Armed and Dangerous: From Undercover Struggle to Freedom (Johannesburg, 2004); F. Mbali, In Transit: Autobiography of a South African Freedom Fighter (Dartford, 2013); J. Slovo, Slovo: The Unfinished Autobiography (London, 1996).

${ }^{5}$ Jack Hodgson wrote a brief account of his family history shortly before he died. HPA A3345, A3.2.7.1, short note by Jack Hodgson on his life, [undated]. Jack Hodgson's widow, Rica Hodgson, a prominent anti-apartheid activist in her own right, has written an autobiography: Foot Soldier for Freedom: A Life in South Africa's Liberation Movement (Johannesburg, 2010).
} 
Second, Hodgson's life is an excellent case study showing how individual lives are not stable but often contradictory, fractured and without coherence. In this, this chapter draws on elements of Ciraj Rasool's critique of historical biography. Rassool argued that South African resistance history and political biographies 'bear the conventional hallmarks of individualism, linearity, order, and coherence'. Life histories were seen to be 'formed by an ordered sequence of acts, events and works, with individuals characterised by stability, autonomy, self-determination and rational choice'. Consequently, biographies produced 'relatively unmessy narratives' where individuals encounter oppression and, in response, become radicalised and politically engaged. ${ }^{6}$ Hodgson's life did not proceed in such an ordered sequence. The earlier and latter parts of his life do not fit easily together. Joe Slovo reflected on this at the memorial which took place after Hodgson's death, noting that Jack Hodgson's experiences during his formative years 'should have turned him into a malevolent, anti-social misfit' and that the Jack he knew 'was disconnected from his past'?

Details about Hodgson's life prior to his active involvement in the struggle against apartheid are virtually unknown and any brief mentions in the secondary literature fall into two categories. First, that his experience as a miner and a soldier gave Hodgson an expertise with explosives which made him a valuable asset in MK. ${ }^{8}$ Second, that his opposition to racial discrimination was consistent throughout his life. ${ }^{9}$ This second assumption appears to be derived from claims made in his obituaries. Anti-Apartheid News claimed that 'for the whole of his adult life he was active in the struggle for a free South Africa', while the South

\footnotetext{
${ }^{6}$ C. Rassool, 'Rethinking Documentary History and South African Political Biography', South African Review of Sociology, 41 (2010), 1, 28-29. Rassool makes this critique at greater length in his doctoral thesis: C. Rassool, 'The Individual, Auto/biography and History in South Africa', (unpublished PhD thesis, University of the Western Cape, 2004). For criticism of Rassool, see J. Hyslop, 'On Biography: A Response to Ciraj Rassool', South African Review of Sociology, 41 (2010), 2, 104-115.

${ }^{7}$ Audio recording of Jack Hodgson's memorial meeting, 18 December 1977. In possession of Hodgson family.

${ }^{8}$ J. Cherry, Umkhonto weSizwe: A Jacana Pocket History (Auckland Park, 2011), 20; S. Ellis, External Mission: The ANC in Exile, 1960-1990 (London, 2012), 11; J. Lazerson, Against the Tide: Whites in the Struggle Against Apartheid (Boulder, 1994), 232; B. Magubane et al., 'The Turn to Armed Struggle', in South African Democracy Education Trust, The Road to Democracy in South Africa: Volume 1 (1960-70) (Cape Town, 2004), 91. Obituaries in South African newspapers noted Hodgson's familiarity with explosives due to his military career and work as a miner. See 'Hodgson trained anti-SA saboteurs', The Star, 9 December 1977 and 'Jack Hodgson dies in London', Cape Times, 6 December 1977.

${ }^{9}$ Lazerson, Against the Tide, 105. See also P. Naidoo, 156 Hands That Built South Africa (Durban, 2006), 235; Simon Zukas, Into Exile and Back (Lusaka, 2002), 71.
} 
African Communist Party noted that 'on the Copperbelt he also helped to defend the rights of his African fellow-workers'. ${ }^{10}$ As will be discussed below, this bears little relationship to Hodgson's actual activities. However, it is not the case that the details in Hodgson's eulogising obituaries were wilfully deceptive. It is more likely that their authors simply did not know about his earlier life, assuming he had always been the man they had known in the anti-apartheid movement and having little or no contact with the people Hodgson associated with in his early life. ${ }^{11}$ For subsequent historians, the problem is a different one: Hodgson's life slipped between different nationally-bound archives, making it more difficult to recover.

Hodgson's childhood and early adult life were hard in a way which was unthinkable for subsequent generations of whites in Southern Africa. Indeed, Thomas Nkobi, then ANC Treasurer General, declared at Hodgson's memorial that 'he chose a life full of hardship and self-sacrifice' instead of enjoying 'the bribery and privilege that is part and parcel of the way of life for whites in South Africa'. ${ }^{12}$ Yet, Hodgson did not choose his hardships. In some ways, it would be straightforward to construct a narrative where the hardships he suffered inspired his revolutionary politics, even though among the many thousands of whites who shared similar experiences, few drew the same conclusions. Hodgson was one of the only people from a white working-class background involved in MK. ${ }^{13}$

\section{Diamonds in the rough: Early years in South Africa}

Hodgson was born in 1910 in Roodeport, a mining town on the West Rand, to parents who had both emigrated from Britain, his father from Hull and his mother from Aberdeen. They had married in South Africa and Hodgson's mother, Jessie, was seven month's pregnant when they married. ${ }^{14}$ Hodgson knew little of his father, who was killed in a mining accident at Durban Deep Mine when Hodgson was just four, but his father left one important

\footnotetext{
10 'Freedom Fighter Dies in London', Anti-Apartheid News, January/February 1978. 'Sad losses to the liberation movement', The African Communist, 73 (second quarter, 1978).

11 Among the 73 letters of condolences received by Rica Hodgson after Jack's death and deposited at the Historical Papers Archive, there is only one from someone who knew Jack Hodgson before 1942. HPA A3345, A3.2.7.1.

${ }^{12}$ Reprinted in 'Jack's fight against fascism', Sechaba, 12 (second quarter, 1978).

13 The other notable individual who shared a similar background is Fred Carneson. T. Lodge, 'Secret Party: South African Communists between 1950 and 1960', South African Historical Journal, 67 (2015), 4, 451.

${ }^{14}$ HPA A3345, A3.2.7.2, Abridged Marriage Certificate: Percy Hodgson and Jessie Turner.
} 
influence: he named his son Percy, after himself, even though 'he detested the name Percy as intensely as I did and gained recognition as Jack Hodgson, as I did; with his fists if necessary'. ${ }^{15}$ After his father's death, Hodgson and his younger brother were sent to an orphanage - where he was beaten and poorly fed - while Jessie Hodgson struggled to support her daughter by working as a waitress. It was only after she married again - to Albert Little, a Scottish miner soon to be stricken with silicosis - two and half years later that the two young boys left the orphanage and could begin school. ${ }^{16}$ His step-father got a job at City Deep Mine on the Central Rand and the family moved into mine housing. They were living on the mine during the 1922 Rand Revolt, a strike by white mineworkers that escalated into an armed insurrection, and would have witnessed the furious fighting around City Deep in March when armed strikers attacked soldiers guarding the property and succeeded in blowing up part of the mine. ${ }^{17}$

Formal education did not last long. Hodgson left school at 13 to start work, only six years after he had begun. He found a job as a leather boy for a few months and then left home for Potchefstroom, where he was apprenticed to a tannery for around two years. ${ }^{18}$ Hodgson was effectively born into the mining industry, however, and it soon drew him in. His father was a miner, his step-father was a miner, his three uncles worked on the mines, and his aunt married a miner. The latter left Hodgson his clothes, including a tweed suit, after he died from silicosis in 1923. The suit fitted. ${ }^{19}$

Aged 16, he returned to the Rand and, lying about his age, secured a job on Consolidated Main Reef Mine as a trainee winding engine driver (a whites-only job responsible for lowering and raising men and ore). It was at this mine that he first encountered trade unionism and suffered the consequences. Hodgson joined the South African Engine Drivers' and Firemen's Association and soon learnt that the union's agreement stipulated that wages for trainees were supposed to increase in increments every six months. Enforcing the 'rate for the job' became an important aspect of his time on Northern Rhodesia's Copperbelt, and Hodgson first tried to organise other trainees around

\footnotetext{
${ }^{15}$ HPA A3345, A3.2.7.1, short note by Jack Hodgson on his life, [undated].

${ }^{16}$ HPA A3345, A3.2.7.2, Marriage Solemnization Certificate, 15 November 1917.

${ }^{17}$ J. Krikler, White Rising: The 1922 Insurrection and Racial Killing in South Africa (Manchester, 2005$), 189$.

${ }^{18}$ HPA A2729 E3, First interview with Jack Hodgson, 17 September 1968.

${ }^{19}$ HPA A3345, A3.2.7.1, short note by Jack Hodgson on his life, [undated].
} 
this principle on the Rand. For his troubles, he was sacked and blacklisted from mines across the Rand. ${ }^{20}$

[map Western Transvaal]

The mid-1920s saw another of the mineral rushes which had been a regular occurrence in Southern Africa since the 1870s. Diamonds were discovered at Lichtenburg in 1926 and thousands flocked to seek their fortune. In 1925, there were 3,679 white diggers and 9,430 African labourers in the whole of the Transvaal Province. By early 1927, there were around 80,000 whites and over 100,000 Africans on the diggings in Lichtenburg District alone. Hodgson arrived in early 1927 and first worked for a butcher but was among the 27,000 people who rushed to Grasfontein when diamond diggings were proclaimed there in March $1927 . .^{21}$

Most shallow deposits, which could easily be worked by an independent digger, were exhausted by October 1926, however, and the riches of the diamond fields mainly accrued to those who owned the farms where alluvial diggings were taking place and who held commercial rights over trading and hawking. ${ }^{22}$ Moreover, the price of Lichtenburg alluvial diamonds collapsed in mid-1927 and threw thousands of diggers into poverty. The diamond fields were one of the places visited by the Carnegie Commission investigation into white poverty in 1929, a study underpinned by ideas of white supremacy and fears of 'racial degeneration'. ${ }^{23}$ Investigators attributed the impoverishment of the diggers to 'the whole atmosphere of the diggings, with their cosmopolitan population, their lack of community feeling or recognised moral standards, and their all-pervading sense of gambling, recklessness and instability'. The Commission lamented that 'many of them have to learn the great lesson that, under modern economic conditions, they can only prosper by hard,

\footnotetext{
${ }^{20}$ HPA A2729 E3, First interview with Jack Hodgson, 17 September 1968.

21 T. Clynick, 'The Lichtenburg Alluvial Diamond Diggers, 1926-1929', African Studies Seminar Paper, University of the Witwatersrand, 21 May 1984, 2-3.

22 T. Clynick, 'Digging a Way into the Working Class': Unemployment and Consciousness amongst the Afrikaner Poor on the Lichtenburg Alluvial Diamond Diggings, 1926-29' in R. Morrell (ed.), White but Poor: Essays on the History of Poor Whites in Southern Africa 1880-1940 (Pretoria, 1992) 80, 86.

${ }^{23}$ T. Willoughby-Herard, Waste of a White Skin: The Carnegie Corporation and the Racial Logic of White Vulnerability (Oakland, CA, 2015).
} 
thorough and regular labour'. ${ }^{24}$ Such was to be the life of Hodgson after leaving the diamond fields and, though he learnt many lessons, he certainly did not prosper.

Scrabbling around in the dirt for diamonds was very different to industrial mining on the Rand and it attracted a different crowd. The diggings had a 'cosmopolitan crowd... There were Australians, Americans and Englishmen, people from all over the world had come to the diamond diggings to get rich quickly, apart from all those who came from SA' ${ }^{25}$ This crowd brought with them a plethora of political influences from around the world. One such individual attracted to Lichtenburg was Solomon Buirski, a South African communist who had spent time in Britain. Buirski taught Communist Party of South Africa (CPSA) study groups for the transient white population on the diamond fields, which Hodgson, then aged sixteen, attended regularly for six months. ${ }^{26}$

A commitment to communism could, at least in South Africa, co-exist comfortably with racist attitudes at the time. Africans did not attend the study groups, nor did Africans and their interests feature as subjects of discussion. Hodgson recalled that, at the time, he simply did not consider Africans to be a part of the working-class. ${ }^{27}$ Although the CPSA had consciously re-orientated towards African workers from 1924, this shift clearly took some time to filter through the communist movement. ${ }^{28}$ In any case, hostility to Africans - or a perspective that African experiences and interests were not relevant - was a central part of the often radical white political culture on the diamond fields. The Diggers' Union, an organisation representing white diggers across South Africa, railed against the diamond magnates who controlled the trade but also demanded racially exclusive protection for white diggers from the South African Government. ${ }^{29}$

The literary culture which Hodgson immersed himself in blended with this general political culture. He read vociferously from an early age and the books he encountered had a huge influence on his life. Reading Charles Darwin, for instance, prompted him to abandon his family's Presbyterian faith and become an atheist. Other major influences included the

\footnotetext{
${ }^{24}$ Clynick, 'Unemployment and Consciousness', 75.

${ }^{25}$ HPA A2729 E3, Fourth interview with Jack Hodgson, 15 October 1968.

${ }^{26}$ Solomon Buirski subsequently taught Joe Slovo, who also became an MK commander. A. Wieder, Ruth First and Joe Slovo in the War Against Apartheid (New York, 2013), 42.

${ }^{27}$ HPA A2729, Third interview with Jack Hodgson, 2 October 1968.

28 A. Drew, Discordant Comrades: Identities and Loyalties on the South African Left (Ashgate, 2000), 71-73, 76-79.

${ }^{29}$ Clynick, 'Unemployment and Consciousness', 95-96.
} 
works of Mark Twain, H.G. Wells, Upton Sinclair, and Sinclair Lewis. What really spoke to Hodgson though, were the books of Jack London, especially The Iron Heel. London was an atheist, socialist writer who had joined the Klondike gold rush in the late 1890s and whose tales of adventure and political tracts were widely popular in the early twentieth century. Hodgson undoubtedly saw similarities in their two lives and he even had a second-degree connection with London: he met a man on the diamond fields who had been with London in the Klondike (or claimed he had). ${ }^{30}$ Significantly, London was also a white supremacist who saw socialism as a means "to give more strength to certain kindred favoured races so that they may survive and inherit the earth to the extinction of the lesser, weaker races." ${ }^{31}$ This combination of opposition to economic exploitation and support for white domination strongly influenced Hodgson's own politics in these years.

The space for the freer life enjoyed by whites on the diamond fields rapidly closed. 'The diggers want to be independent and they want to remain independent. They do not want to work for others' declared the Diggers' Union, but independence was short-lived. ${ }^{32}$ On the diamond fields, Hodgson pegged claims in several rushes and lived a hand-to-mouth existence doing any job he could obtain. Even after he was joined by his younger brother, they were too poor to afford African labour and insufficiently wily to take advantage of diamond smuggling from fields in Namaqualand owned by De Beers and closed to diggers. In early 1929, he left for the platinum mines at Rustenburg, some $140 \mathrm{~km}$ away. The reasons he left were simple: 'Because I was broke. There was nothing else to do. I needed the work so I walked all the way to Rustenburg. Good reason. Why did the chicken cross the road? ${ }^{33}$

In his later years, Hodgson openly acknowledged that he had racist attitudes during the 1920s and acted upon them. During interviews conducted in 1968, he recalled that his first criminal charge 'arose out of something that was essentially anti-Semitic' as he became involved in a large-scale brawl with a group of Jewish traders that ended with their stall being burnt to the ground. ${ }^{34}$ However, he also recalled that he had beaten up an African man whom he suspected of stealing from a Jewish friends' clothing stall, and he characterised his interactions with Africans during this period as either joking with them or shouting at them. ${ }^{35}$

\footnotetext{
${ }^{30}$ HPA A2729 E3, Fourth interview with Jack Hodgson, 15 October 1968.

${ }^{31}$ Quoted in Jay Williams, The Oxford Handbook of Jack London, (New York, 2017), 263.

32 Clynick, 'Unemployment and Consciousness', 97.

${ }^{33}$ HPA A2729 E3, Second interview with Jack Hodgson, 24 September 1968.

${ }^{34}$ Ibid.

${ }^{35}$ Ibid., Third interview with Jack Hodgson, 2 October 1968.
} 
During these same interviews, however, Hodgson was more selective about his beliefs and activities during his time on the Copperbelt in Northern Rhodesia, perhaps because, rather than reflecting the racist beliefs of the society he lived in, on the Copperbelt he propagated them.

[map Copperbelt, 1930s]

\section{Going underground: Industrial life and struggles on the Copperbelt}

The copper industry was booming in the 1920s and the two mining companies which had gained control over the Northern Rhodesian Copperbelt - the Rhodesian Selection Trust (RST) and Rhodesian Anglo American (RAA) - sought to begin production as quickly as possible. Men like Hodgson were in demand and thousands of white mineworkers and construction workers flocked to the Copperbelt. Hodgson's step-father had already gone to the Copperbelt and suggested that Hodgson do the same. It didn't take much to persuade Hodgson, especially as both his parents had moved across the British Empire to secure better opportunities for themselves. He arrived at Nkana, one of the largest mines then in development, in 1929. Using skills he had picked up during brief stints working on Eerste Geluk Mine and Waterval Mine in Rustenburg in South Africa, Hodgson secured work first as an operator in the power plant at RAA's Nkana Mine, and then worked for a contractor painting newly-erected chimneys and constructing the steel frames of new surface plants. ${ }^{36}$

There was a similar kind of rough cosmopolitanism on the Copperbelt as Hodgson had encountered on the diamond fields. White workers came from all over the Englishspeaking world on short-term contracts. At Nkana, Hodgson worked as a steel-erector alongside Glaswegian riveters, skilled workers who bolted together metal plates and beams in ships and buildings, and lived in a single-roomed hut with an Australian miner, who used to drink an entire bottle of gin every day. Both men also carried guns with them everywhere, like many other whites on the Copperbelt. ${ }^{37}$ Yet the real danger came not from gin-slugging, gun-slinging white miners, but from disease. So many whites were struck down with malaria and blackwater fever that white workers from across Southern Africa began to avoid the

\footnotetext{
${ }^{36} \mathrm{Ibid}$., Fourth interview with Jack Hodgson, 15 October 1968.

${ }^{37}$ Ibid.
} 
Copperbelt. ${ }^{38}$ Hodgson himself contracted cerebral malaria in mid-1930 and lost his job, since the mines had no provision for sick pay. Instead, he was forced to return to South Africa to recuperate and could only get back to the Copperbelt by borrowing money from a boarding house in Nkana. ${ }^{39}$

Along with their industrial skills, whites from mining and industrial centres all around the world brought with them a whole array of radical political influences: Glaswegian riveters deeply imbued with the culture of 'Red Clydeside', syndicalist miners from the copper camps of the American West, veterans of the Rand Revolt, these were the men who Hodgson rubbed shoulders with. This was the political culture he was immersed in during his entire period on the Copperbelt. Later, when he lived at Mufulira, his neighbour was the son of Harry Spendiff, an insurrectionary leader of the Rand Revolt who had committed suicide rather than be captured by government troops. ${ }^{40}$ It was on the Copperbelt that Hodgson joined the Left Book Club - established by British socialists in 1936 - and came to acquire books like Karl Marx's Capital: Volume I, Hewlett Johnson's The Socialist Sixth of the World, which extolled the virtues of the Soviet Union, and Ellen Wilkinson's The Town that was Murdered, a harrowing account of poverty in Britain during the Great Depression. It was also on the Copperbelt that he first considered himself to be a communist.

Hodgson's radical politics were not unusual on the Copperbelt. Many white mineworkers regarded themselves as part of an international white working-class and had an international outlook. Furious debates took place about subjects like the Spanish Civil War, yet whites who regarded themselves as working-class rarely reflected on the interests of Africans on the Copperbelt, who constituted the large majority of the mine's workforce. ${ }^{41}$ Attitudes towards the Africans who did the toughest jobs on the mines and in white households for low pay ranged from disinterest to active hostility. Like most other whites, Hodgson employed at least one male African servant from the time he arrived on the Copperbelt and had authority over others in the workplace.

The number of Africans Hodgson had direct authority over increased dramatically when he started working underground around 1932. He had been 'reluctant to go underground as a miner' as his father had been killed in an underground accident, his step-

\footnotetext{
38 L. Schumaker, 'Slimes and Death-Dealing Dambos: Water, Industry and the Garden City on Zambia's Copperbelt', Journal of Southern African Studies, 34 (2008), 4, 824-825.

${ }^{39}$ HPA A2729 E3, Fourth interview with Jack Hodgson, 15 October 1968.

${ }^{40}$ Interview with Dawn Hodgson, 10 January 2017.

${ }^{41}$ HPA A2729 E3, Sixth interview with Jack Hodgson, 4 November 1968.
} 
father debilitated by silicosis, and he had begun his working life wearing the clothes of a dead miner, his uncle. ${ }^{42}$ The Great Depression effectively forced him underground as construction work ceased on all Copperbelt mines. Hodgson was not laid off, unlike thousands of others, but spent a year on night-shift as a scraperman, clearing out waste rock created by the blasting of new tunnels with a group of African subordinates at times dozens strong.

In 1933, with the depression easing, new shafts were sunk at Nkana Mine. Hodgson secured lucrative work as a shaft-sinker and then began working as a contract miner, first at Nkana and then from around 1936 at RST's Mufulira Mine. After years of drifting between jobs, Hodgson now had a job that was relatively secure and well-paid, so long as copper prices held up. ${ }^{43}$ Contract miners were paid by footage mined and supervised a group of around 12 African miners who did most of the manual work, though unlike in South Africa, white miners on the Copperbelt were not responsible for paying African miners out of their own wage packet, and this reduced tensions underground.

Another element of stability developed at the same time: Jack Hodgson became a family man. In July 1934, he married Esperanza Rosa Ruiter (known as Peggy from an early age), a young South African woman whose family had emigrated from Italy. The two families had known each other in Johannesburg and Jack and Peggy had first met there as children. The couple lived as most other whites did on the Copperbelt, in a modest detached house provided by the mine with African servants. More family arrived on the Copperbelt. Peggy's brother Peter came to work on the Copperbelt mines, as did Jack's younger brother George. Jack and Peggy had three children in three years, the eldest of whom Jack named Percy. However, his daughter recalled he didn't interact much with his children at that time. He was always busy, and they were usually asleep by the time he came off shift. ${ }^{44}$

Greater stability in his life encouraged Hodgson to re-engage with the trade union movement for the first time since being blacklisted on the Rand. On the Rustenburg platinum mines, his 'period of working there was of such transient nature, that I never felt at any stage that I had a need to become involved' but now he had a more secure position. ${ }^{45}$ Hodgson was involved in efforts to form an industrial union for all white mineworkers on the Copperbelt mines from the outset in 1934, when the idea was first publicly proposed by Richard Olds, a

\footnotetext{
42 Ibid., Fifth interview with Jack Hodgson, 22 October 1968.

${ }^{43}$ Ibid., Sixth interview with Jack Hodgson, 4 November 1968.

${ }^{44}$ Interview with Dawn Hodgson, 10 January 2017.

${ }^{45}$ HPA A2729, Third interview with Jack Hodgson, 2 October 1968.
} 
British mineworker. ${ }^{46}$ Olds made the purpose of this organisation, and the basis on which it was to be organised, very clear:

The white worker in Northern Rhodesia is faced with two alternatives viz. to either organise against the encroachment of the Native in their skilled trades or get ready to leave the country.

Who have we today who will champion the cause of the white population, Where are the Men who can think WHITE and will stand out and fight the cause of the white worker and his children?

Are we going to maintain our WHITE STANDARD or allow ourselves to descend to the level of the blacks by always thinking BLACK. ${ }^{47}$

These were politics Hodgson was entirely comfortable with at the time and these attitudes sat alongside his commitment to communism. He regarded the whites-only mineworkers' union as an avenue for radical politics and helped produce a paper called The Mineworker, which published articles praising the Soviet Union and warning about the rise of fascism. ${ }^{48}$ The first incarnation of the union proved ineffective, however, and it was thoroughly reorganised in Ndola in December 1938 when 19 men met to form the first General Council, Hodgson among them. Fearing retaliation from the mining companies, reorganisation was conducted surreptitiously and each man signed a pledge to keep 'all we may learn of the administration and affairs of the union as strictly secret' ${ }^{49}$

Despite the secrecy, Hodgson's contemporary political ideas and actions come into clear focus during the tumultuous war years of the early 1940s. Copper from the Copperbelt made a crucial contribution to Britain's war effort. So, in early 1940, a group of white mineworkers resolved to use the opportunity presented by heightened wartime demand for copper to settle longstanding grievances over pay and conditions. Hodgson was at the centre of this and called for immediate strikes to win their demands, reflecting years later that, at the

\footnotetext{
46 'To form workers' federation', Bulawayo Chronicle, 15 September 1934. Industrial unions aimed to organise all workers within the same industry, as opposed to unions which organised along a trade or craft basis, a type of organisation which predominated in South Africa.

47 Zambia Consolidated Copper Mines Archive, Ndola (ZCCM), 10.7.9A, Letter from R. Olds, Copperbelt Times, 12 October 1934.

${ }^{48}$ HPA A2729, Sixth interview with Jack Hodgson, 4 November 1968.

${ }^{49}$ M. Mwendapole, A History of the Trade Union Movement in Zambia up to 1968 (Lusaka, 1977), 6.
} 
time, 'I [didn't] think I had the ability to be subtle about anything' ${ }^{50}$ More cautious members of the union leadership refused to countenance a strike, believing one was not possible as the workforce was 'too much a cosmopolitan lot'. Hodgson and Frank Maybank, a recentlyarrived British miner, were not prepared to take no for an answer and 'got together all the militants we knew and a strike was worked out'. ${ }^{51}$

At a riotous public meeting in Mufulira, where local union leaders were thrown out, the plan was endorsed and at 5am on 17 March 1940, this group of militants blocked the road to the main shaft at Mufulira Mine. They had no qualms about disrupting the war effort and neither, it transpired, did much of the rest of the white workforce as not a single white mineworker crossed the picket line. Hodgson and others addressed the crowd of strikers gathered around the shaft and urged them to spread the strike. ${ }^{52}$ Four days later, white mineworkers walked out at Nkana Mine - Hodgson's previous employer - after a similarly heated public meeting.

[picture Jack Hodgson addressing strikers Mufulira]

At both mines, African mineworkers initially went underground, and no effort was made to involve them in the dispute, to explain why thousands of them were thrown out of work, or to denounce them for crossing picket lines. Africans were not part of the working-class, which mirrored the view of the colonial authorities that Africans were not to become permanent urban workers, so were to be kept out of the dispute. This attitude was made explicit at the public meeting preceding the strike at Nkana where the consensus was that 'Africans should remain in their compounds'. ${ }^{53}$ African mineworkers themselves had different ideas and thousands came out on strike at Nkana and Mufulira immediately after the white mineworkers' strike. This dispute culminated in a protest at Nkana where soldiers opened fire on the crowd after some strikers pelted them with stones, killing 17 and injuring around $65 .{ }^{54}$

Sympathy from white mineworkers after this blood-letting was muted at best. Several white mineworkers were called to give evidence to the Forster Commission established to

\footnotetext{
${ }^{50}$ HPA A2729 E3, Seventh interview with Jack Hodgson, 12 November 1968.

${ }^{51}$ Ibid., Sixth interview with Jack Hodgson, 4 November 1968.

${ }^{52}$ The National Archives, Kew (TNA), CO 795/117/2, Testimony of Gilbert Howe, 17 May 1940.

${ }^{53}$ ZCCM 3.8.1A, Notes of meeting of Mine Workers Held in Cinema Hall, Nkana, 19 March 1940.

${ }^{54}$ I. Henderson, 'Early African Leadership: The Copperbelt Disturbances of 1935 and 1940', Journal of Southern African Studies, 2 (1975), 1, 92.
} 
investigate the African strike and subsequent shooting, including Hodgson. ${ }^{55}$ African witnesses had complained to the Commission about being assaulted by white miners underground, but Hodgson used the opportunity to complain that Africans often:

deliberately caused a white man to strike them, with the object of getting him fired. It has happened on so many occasions that we are beginning to think that the Native is adopting that attitude in a spirit of antagonism.

He also reiterated his conviction that the mineworkers' union should be for white men only and called for greater control of African labour underground. ${ }^{56}$ This control was to be provided by white mineworkers themselves. The union demanded a colour bar and that all African labour be under the direct supervision of a white mineworker (which would have significantly increased their numbers), both demands Hodgson supported. At a meeting with mine management a few days before the Forster Commission hearings, Hodgson had threatened 'that if the white man's livelihood were threatened to any serious extent the European could close the Mine. There must be some limit to which the native could rise' ${ }^{57}$

At the same meeting, representatives of the white mineworkers' union demanded that the 'rate for the job' be adhered to; if Africans were to perform the same jobs as Europeans, they should be paid the same wages, banking on the fact that the mining companies had no intention of doing this. This was widely understood as a justification for enforcing a colour bar. Charlie Harris, then general secretary of the South African Mine Workers' Union (SAMWU), explicitly advised a meeting in Luanshya in 1936, which Hodgson likely attended, to win support for a colour bar by phrasing their demands as the 'rate for the job' because British trade unions '[could] not understand our difficulties in preserving the white races' ${ }^{58}$ Similarly, the whites-only Rhodesia Railway Workers' Union regarded the 'rate for the job' argument as 'subterfuge' because 'equal pay for equal work mean[t] a colour bar'. ${ }^{59}$

\footnotetext{
${ }^{55}$ Report of the Commission Appointed to Inquire into the Disturbances in the Copperbelt, Northern Rhodesia (Lusaka, July 1940).

${ }^{56}$ TNA CO 795/117/2, Testimony of Jack Hodgson, 29 May 1940.

${ }^{57}$ ZCCM 12.2.10C, 'Colour Bar' in agreement between the companies and the Northern Rhodesia Mine Workers' Union.

58 'The labour meeting at Luanshya last Saturday', The Mineworker, July 1936.

${ }^{59}$ R. Welensky, 'Africans and Trade Unions in Northern Rhodesia', African Affairs, 45 (1946), 181.
} 
Yet the slogan underpinned efforts to defend the colour bar until the 1960s, and was endorsed even by radicals among the Copperbelt's white workforce like Frank Maybank.

Hodgson seems to have developed a close affinity with Maybank. Although they only worked underground together at Mufulira Mine for around a year, they quickly became collaborators and kept up an irregular correspondence for decades afterwards. According to Hodgson, Maybank was 'an old hand' who 'taught me a lot of tricks' and encouraged him to take an active role and speak at meetings. ${ }^{60}$ Maybank was a veteran communist who had toured the Soviet Union and met figures in the international labour movement who Hodgson had only read about. The two men not only had similar politics but similar backgrounds. Like Hodgson, Maybank was sent to an orphanage after the death of his father and had spent years living an itinerant lifestyle working the same kind of jobs as Hodgson: construction, digging in gold rushes, and mine work in Australia and New Zealand. ${ }^{61}$

The reason the two spent such a short time working together was that Hodgson was removed from the Copperbelt in October 1940 after he and his family went on holiday to Durban. When Hodgson attempted to return to Northern Rhodesia, he was stopped at Johannesburg's Park Station by two military officers who informed him that he would be interned if he returned. ${ }^{62}$ This was an unsurprising turn of events. Shortly before leaving the Copperbelt, he had been part of a union delegation which threatened the mine management that 'they would have to get the closed shop and, if necessary, might have to go to extreme ends to get it'. At the same meeting, for good measure, Hodgson also demanded the expulsion of the Roan Antelope Mine Manager from Northern Rhodesia and pay increases for artisans. ${ }^{63}$

\section{Behind enemy lines: Experiences during the Second World War}

Having lost his job and with no prospect of work on the Rand mines - having been blacklisted in the mid-1920s - Hodgson needed to make a decision about his future, and made it quickly. On 30 November, he enlisted in the army in Pietermaritzburg, where the

\footnotetext{
${ }^{60}$ HPA A2729 E3, Seventh interview with Jack Hodgson, 12 November 1968.

61 'The Story of the Life of a Man', Personal papers of Frank Maybank, in author's possession.

${ }^{62}$ HPA A2729 E3, Eighth interview with Jack Hodgson, 19 November 1968.

${ }^{63}$ National Archives of Zambia, Lusaka, SEC1/1420, Notes on a meeting between the Mine Managements and the N.R. Mine Workers' Union, 18 September 1940.
} 
family had been staying with his mother's cousin. ${ }^{64}$ This was fortuitous timing as the army had just begun making a concerted effort to recruit skilled industrial workers who could operate and repair new military hardware such as tanks. ${ }^{65}$ Hodgson joined the $4^{\text {th }}$ South African Armoured Car Regiment and by May 1941 was in North Africa.

[picture Hodgson's desert rat patch]

On arrival in Egypt, Hodgson was attached to the $11^{\text {th }}$ Hussars, a British Army regiment then deployed as part of the $7^{\text {th }}$ Armoured Division, better known by the nickname they acquired: the 'Desert Rats' ${ }^{66} \mathrm{He}$ had arrived in North Africa in time to participate in some of the heaviest fighting in the region as Nazi Germany's Afrika Corps launched a ferocious counterattack following the collapse of the Italian army in Libya in early 1941. Hodgson fought behind enemy lines, making rapid hit-and-run attacks, and was involved in the fighting to control the Halfaya Pass on the Libya-Egypt border, which raged from May to November 1941 and was so severe that the area was nicknamed the 'Hellfire Pass' ${ }^{67}$

For the short time he was at the front, Hodgson did well in the army. Although he 'was known as the Bolshevik in [the] regiment', he rose to the rank of Acting Sergeant and kept a clean conduct sheet. ${ }^{68}$ However, fighting took a heavy toll. In March 1942, he was shipped back to South Africa suffering from duodenal ulcers and internal bleeding. ${ }^{69}$ Hodgson jokingly blamed the ulcers on the decisions he had to make during combat, and they left him with health problems that plagued him for the rest of his life. When Rusty Bernstein, later a defendant in the 1963-64 Rivonia Trial, during which key leaders of the anti-apartheid movement including Nelson Mandela were jailed, first met Hodgson at the CPSA's Johannesburg office in mid-1942 he encountered a man who 'was about my age, but gaunt

\footnotetext{
${ }^{64}$ South African National Defence Force Documentation Centre, Pretoria (DC), Attestation of Percy John Hodgson (178459).

${ }^{65}$ N. Roos, Ordinary Springboks: White Servicemen and Social Justice in South Africa, 1939-1961 (Aldershot, 2005), 30 .

${ }^{66}$ DC, Application for Campaign Medals: Percy John Hodgson.

${ }^{67}$ For a detailed study of the war in the Western Desert see B. Pitt, The Crucible of War (3 vols.) (London, 1986).

${ }^{68}$ HPA A2729 E3, Eighth interview with Jack Hodgson, 19 November 1968.

${ }^{69}$ DC, Particulars of Discharge: Percy John Hodgson.
} 
and hollow cheeked as though all flesh had melted off his bones' ${ }^{70}$ Hodgson was discharged on medical grounds in May 1943.

The Second World War left a deep impression on many of the white communists who fought with the South African forces. ${ }^{71}$ Yet, initially, Hodgson was more closely concerned with the white labour movement in Northern Rhodesia. He received news about the Copperbelt from Maybank and Roy Welensky - a trade unionist on Rhodesia Railways who later became a prominent settler politician - and regarded both men 'as being something closer than friends'.72 Poor health inhibited a more active role in politics and he was hospitalised four times during 1942 and 1943. For the first time since aged 13 he was without a job and likely used the opportunity to read political material vociferously. During his longest spell in a military hospital (from 27 August to 23 November 1942) he was sought out by Chris Meyer, a radical white miner who had worked alongside Hodgson at Mufulira. Meyer brought dramatic news: he had been deported from Northern Rhodesia while Maybank had been arrested by the army and was awaiting deportation. ${ }^{73}$

Both Jack and Peggy Hodgson threw themselves into the campaign organised by white trades unions in Johannesburg to get Maybank released. ${ }^{74} \mathrm{He}$ lobbied white trade unions such as the SAMWU for support and accompanied their delegations to government ministers and General Smuts. Hodgson was privately critical of the SAMWU - advising trade unionists on the Copperbelt to use General Secretary Bertie Broderick but not to trust him. His critical attitude, however, was caused by the corruption of the union leadership and not its overt hostility to Africans. ${ }^{75}$ Yet, there were some signs that his politics had changed. At a public meeting, Hodgson proclaimed his support for the strike by African mineworkers on the Copperbelt in 1940, though disingenuously claimed that 'the European workers lay unable to help them' ${ }^{76}$ Hodgson's close concern with the Copperbelt is most clearly demonstrated

\footnotetext{
${ }^{70}$ Bernstein, Memory Against Forgetting, 64.

${ }^{71}$ Lodge, 'Secret Party', 441. Neil Roos has written on the impact of the war more generally on the 200,000 white South African volunteers: Roos, Ordinary Springbooks.

72 HPA A2729 E3, Eighth interview with Jack Hodgson, 19 November 1968.

${ }^{73}$ Hodgson was close to Meyer and the two families shared a house on his release from hospital. Bernstein, Memory, 65.

74 Duncan Money, 'The World of European Labour on the Northern Rhodesian Copperbelt, 1940-1945', International Review of Social History, 60 (2015), 2, 242-252.

75 HPA AH 646 Dc12.20, letter from P.J. Hodgson to General Council, Northern Rhodesia Mine Workers' Union, [undated].

${ }^{76}$ National Archives of South Africa, Pretoria, BTS 9/77/6A, Secret Report on Chris Meyer, 1 December 1942.
} 
when the campaign failed and Maybank was deported, leaving the position of General Secretary of the white mineworkers' union vacant. Hodgson was offered the job and attempted to return to the Copperbelt to lead a union which, by this time, was successfully enforcing an industrial colour bar. However, the Northern Rhodesia Government informed him that he would not be allowed to enter the territory. ${ }^{77}$

Hodgson had joined the CPSA while in the army, and the party indicated to him that, failing to return to the Copperbelt, he should join the leadership of Springbok Legion, a newly-formed progressive soldiers' trade union. ${ }^{78} \mathrm{He}$ became the Legion's National Secretary, a position he held for ten years, while Peggy also joined the Legion's staff. ${ }^{79}$ Hodgson's active involvement in the CPSA was part of a small but not insignificant influx of support for the party and an unprecedented growth in its respectability owing to the war-time alliance between Western countries and the Soviet Union. Membership quadrupled between 1941 and 1943 and the Friends of the Soviet Union, an organisation established by the CPSA, secured the Minister of Justice and Mayor of Johannesburg as patrons. ${ }^{80}$ But the moment was short-lived, as was the success of the Springbok Legion. From a mass movement of soldiers and veterans over 55,000 strong in 1944, the Legion rapidly atrophied to a handful of activists after the war. The ideas of the Legion's radical leadership 'of a unified, non-racial South African working-class was anathema to most white ex-servicemen, whose hopes for the post-war world were premised on a range of racialized assumptions', ${ }^{81}$

It was under the auspices of the Springbok Legion that Hodgson travelled to Cape Town in 1943 to meet local activists there, one of whom was a young Jewish woman named Rica Gampel. ${ }^{82}$ Rica shared fond memories of the first time she met Jack and how they quickly grew close: 'it was one of those things like you read about and don't really believe that it was true - it was kind of like that' ${ }^{83}$ Her marriage to a sailor in the South African Navy was already breaking down, and Jack and Peggy soon separated as well. After their

\footnotetext{
${ }^{77}$ HPA A2729 E3, Eighth interview with Jack Hodgson, 19 November 1968.

${ }^{78}$ Ibid.

${ }^{79}$ Roos, Ordinary Springbooks, 75-76.

${ }^{80}$ B. White, 'The Role of the Springbok Legion in the Communist Party of South Africa's Common Front Strategy, 1941-1950', Kleio, 25 (1993), 1, 97.

${ }^{81}$ N. Roos, 'The Springbok and the Skunk: War Veterans and the Politics of Whiteness in South Africa during the 1940s and 1950s', Journal of Southern African Studies, 35 (2009), 3, 657.

${ }^{82}$ Hodgson, Foot Soldier, 38.

${ }^{83}$ South African History Archive, Johannesburg, (SAHA) AL 2460 A08.05, Interview with Rica Hodgson [undated].
} 
respective divorces had been finalised, Jack and Rica married in August 1945. ${ }^{84}$ Jack and Peggy's divorce seems to have been amicable. Their daughter recalled that the two were friendly when they met at social occasions, and Peggy, who joined the army in 1943 and was posted to Durban, became friends with Rica's sister, who lived there. ${ }^{85}$

\section{Conclusion}

This new marriage characterised the abrupt rupture in Jack Hodgson's life. His self-identity as a white worker, a seemingly robust one developed and reinforced over a long time upon, dissolved with remarkable rapidity. He disengaged almost entirely from the white labour movement that had been at the centre of his life. His politics and attitudes changed as well. When asked 'did he [Jack Hodgson] impress you in the way he related with black people,' Rica replied, 'yes, it did impress me, but what impressed me was that he had so many friends amongst them'. ${ }^{86}$ There is no reason to doubt that this was the case. By this time, Hodgson was national secretary of a non-racial organisation, the Springbok Legion, and had joined the Communist Party, which had a predominantly African membership. ${ }^{87}$ Yet this was only three years after he had been at the forefront of efforts to frustrate African aspirations on the Copperbelt by agitating for a colour bar, and a year after he had sought to lead the union enforcing this colour bar.

Hodgson's biography is one which is non-linear and unstable. The Springbok Legion certainly gave him greater opportunity to reflect on the ideological implications of fighting fascism, and took him away from workplaces where he would have direct authority over African workers and been a member of a white trade union. Yet his changing ideas were not a kind of mechanical response to new experiences, something illustrated by the fact that so many others went through the same experiences as Hodgson did. Virtually none of the tens of thousands who passed through the Springbok Legion came to the same conclusions which he did, although many would also have had personal experiences of pre-war hardship during the Depression years. There were plenty of other radicals among the Copperbelt's white

\footnotetext{
84 'Congrats', Fighting Talk, September 1945.

${ }^{85}$ Interview with Dawn Hodgson, 10 January 2017.

${ }^{86}$ SAHA, AL 2460 A08.05, Interview with Rica Hodgson [undated].

${ }^{87}$ D. Everatt, The Origins of Non-Racialism: White Opposition to Apartheid in the 1950s (Johannesburg, 2009),

21.
} 
workforce, several of whom fought in the war, but they remained ardent supporters of the colour bar. It would be more explicable if all the experiences of the first decades of Hodgson's life had produced a resolute supporter of apartheid, as many of the poor whites and white mineworkers he lived and worked alongside became.

Continuities in Hodgson's life reveal how much changed. Both when he was an antagonistic shop steward in a whites-only trade union and when he was a militant antiapartheid activist, Hodgson considered himself to be a communist. What it meant to be a political radical in Southern Africa had, however, altered considerably between those two moments in his life. The other major continuity is violence. Hodgson inhabited a violent world and the changes in his life mostly brought changes in the scale and targets of the violence he had encountered from the very beginning of his life. He was beaten at an orphanage as a young child, fought to gain recognition as 'Jack' from an early age after being christened by his father with a name he hated, survived brawls and shootings in what he termed the 'Wild West business' of diamond diggings as a teenager, worked alongside hardbitten, gun-toting miners in the Copperbelt camps in his twenties, endured the hazards of underground mining which had killed several of his family members, took to the floor at riotous mass meetings to instigate showdowns with the mining bosses, and faced down the tanks of the Afrika Corps in fierce combat in North Africa. ${ }^{88}$ All this before he became involved in the anti-apartheid movement and helped to establish MK.

In some ways, Hodgson was a remnant of a world which had disappeared by the late 1940s, a time when Johannesburg was convulsed by wildcat strikes and revolutionary upheavals by whites. Reflecting on the Rand Revolt, South African socialist Wilfred Harrison recalled that in Johannesburg some 50,000 whites had marched behind a red flag in the funeral procession of three strikers who had gone to gallows singing internationalist socialist song 'The Red Flag', but:

That is many years ago and we may wonder what has become of those 50,000 people who followed those singers of the 'Red Flag' to their graves. Obviously they have buried the axe, so to speak, and their indignation against Capitalist machinations. ${ }^{89}$

Jack Hodgson never buried the axe. His life was a life of struggle, but his were very different struggles in different times.

\footnotetext{
${ }^{88}$ HPA A2729 E3, First interview with Jack Hodgson, 17 September 1968.

${ }^{89}$ Wilfred Harrison, Memoirs of a Socialist in South Africa, 1903-1947 (Cape Town, 1947), 48.
} 